\title{
Adrenergic Receptor
}

National Cancer Institute

\section{Source}

National Cancer Institute. Adrenergic Receptor. NCI Thesaurus. Code C105824.

A family of $\mathrm{G}$ protein-coupled receptors that bind catecholamines and play a role in the stimulation of the sympathetic nervous system. 